\title{
Rhetorical Metaphor in Barrack Obama Speech Family
}

\author{
Roby Hariyanto Gunawan; lalu Muhaimi; Amrullah \\ English Graduate Department, Faculty of Teacher Training and Education,University of Mataram, Indonesia
}

\begin{abstract}
Speech is communication to share information method the main point of successful speech cannot measuring by loud applause of the audience but also the audience can understand with what the speaker idea. Some people communicate with each other more than they said or have hidden meaning in their speech. Being one of the most powerful Presidents in the history of the United States, Obama has been asserting himself among the American people. This research is considered as stylistic of language that focuses on metaphor analysis since it explores the style by President of United State Barrack Osama in speech address of Berlin 2008. The objective of this study is to know the word metaphor that used by Barrack Obama and what indicate of metaphor speech by Barrack Obama. This research employed a descriptive method was used since this research focus on describing the used of rhetorical metaphor in barrack Obama Speech address of Berlin. The main data of this research is taken by speech Barrack Obama in American Rhetoric. The technique of data collection in this research was note taking where the researcher give sign to the speech after that describing the data. The researcher applied textual analysis since he referred to the theories of the research since analyzing data. Result of this study reveals the following finding, there are 9 phrases containing metaphor in Barrack Obama speech in Address to the People in Berlin when he spoke to the audience, the meaning of speeches is various. Every phrases or word described in this research. From the data of that speech the researcher could be concluded the rhetorical metaphor is important and have influence to become more powerful of the speech.
\end{abstract}

Keywords: Rhetorical; Metaphor; Barrack Obama

\section{Introduction}

Speech, as one of the communication methods of conveying information, has been gaining no less importance whether in the past and nowadays or in the West and the East, thanks to its uniqueness from other kinds of talk and strong influence on audience, many people, especially politicians usually take full advantage of it to convince their targeted audience to achieve their political ends. This is a cheap and effective way of gaining support. However, a successful speech needs not only the speaker's eloquence but also a decent speech craft, in which many skills are used. Among them are proper rhetorical devices added to make the speech more encouraging and mesmerizing.

One of the most famous speaker in the world base on in political speech is president of United States in the twenty-first century, Barack H. Obama, he is the first of president from black color in the united states of America in history and he also grows up in Indonesia, has conducted since his speech during political career in America and another countries in the world. Where his speech of president to 
communicate with another people including his speech have meaning or meaning in other word his spoke has hidden meaning noted statesmen at present. Therefore, it is never unnecessary to make an analysis of rhetorical metaphor applied in his public speeches, thereby, from that point of the explanations, researcher focused on the objective of this study of Barrack Obama speech in rhetorical metaphor by speaker and readers can learn a lot from his speech that used and the skills.

Where the style of leader that used in their speeches that called rhetoric. Rhetoric means the persuasive speaking of someone to help the speaker produce an affective his speech or to conveying the audience with his idea that spoke. In using rhetoric the speaker made inspirable of his statement to persuade another people or listener; therefore, both rhetoric and persuasion are inseparable of definitions of rhetoric including the idea of persuasion what word his spoke to the audiences believe about information. Rhetoric is an important think to analyze in this study in recent situation in significance of public speech in political, social, and in current issues of life. Rhetoric in technique will make speaker felt self-confidence and give certainty what the speaker concerned (hendrikus, 1991) in other explanation in rhetoric of leader using to control people. The audiences are persuading when the speaker's rhetoric is successful, Therefore, to be able produce the impression speech of a good idea, everyone should be able to give the idea of knowledge of rhetoric when speech, related also with the selection of speech.

Speech is a form of monologist part of science to speak in the current part of rhetoric. This research aim to find the rhetorical used in Barrack Obama since in theme of his speech in Germany where the condition of this research focus on the rhetorical of metaphor speech.

\section{Rhetoric}

Rhetoric is an art of language that used by speaker to give influence the audience. Rhetoric is an ability of the speaker more effectively. Every speaker who wanted their communication effectively or to give impact had to study rhetoric clearly. Rhetoric used to make ideas or utterance know about what the speaker says. The word rhetoric is developed by ancient Greek in public speaking rhetoric (Zheng Lingling,2014). In other means, rhetoric is learning to be great speaker when saying something.

Aristoteles was the first person that recognized rhetoric as an art of language. He is the father of rhetoric communication. Aristoteles has three major things such as: the truth and logical language that being said, how the speaker conveying the audience trust and emotion of the speaker awake accept idea. In rhetoric effectively people learn how to manage logic argumentation for audience and how to say something persuasively. In other perspective rhetoric is subject that is concerned with the employment of the discourse, in written situation or spoken situation, to motivate hearer or the audience, whether the hearer in individual person or composed of group of people when giving information in communications generally (Corbet,1971). in its definition rhetoric as the process of speaking to a group of people intentionally and intended to inform, influence or entertain listeners (Yanuarita, 2012).

From some notions of rhetoric stated above, the definition of rhetoric in general is to suggest that all refer to and emphasize the ability to use spoken language (speaking) that is good by giving a touch of style (art) in its delivery with the aim of binding/arousing the hearts of listeners and understanding what speaker spoke.

\section{Metaphor}

Metaphor is part of the figurative language. Understanding Metaphor is an illustration that describes something with a precise and direct comparison on the basis of almost the same or the same nature. Another definition mentions that the metaphorical cycle is the use of groups of words or words that are not the actual meaning of the word, but as an illustration based on comparison or equation. Which is a feature of the metaphorical form, namely the use of figurative words and the choice of words that equate things to other things. The metaphorical rank is included in the comparison group. Metaphorical 
terms in comparing or equating things, using direct comparisons without the comparison words that follow it like.

Metaphor contains elements that are sometimes not explicitly mentioned. The definition of metaphor according to Beekman and Callow (1974, is an implicit comparison. Metaphor mentioned is a form of comparison of two things directly, but in a short form. The style of metaphor sees something by means of other objects. Metaphor as a direct comparison does not use words such as and so on, so that the first principal is directly related to the second another subject of the compared elements, namely image, has a number of components of meaning and is usually only one of the components of meaning that is relevant and also possessed by the second element, namely the topic. Keraf calls metaphor included in the style of figurative language. This style is first formed based on comparison or equation.

Comparing something with something else, means trying to find traits that show similarities between the two things. Contains two meanings, namely comparisons including dal am the language style. Based on this explanation you can see the difference between direct language style and figurative language style. Lakof (2003) says that ordinary or direct comparisons include two members belonging to the same class of words, while comparisons in the form of figurative language include two things belonging to different classes of words that the function to give the audience understand what the speakers say or all the human spoke has meaning to communicate in abstract thing and real.

\section{Method}

This research of project has two main point of problem to be answer. They are what are the metapors language used in the address to the people of Berlin of Barrack Obama's and what do the metaphor used in the address indicate. In this research, the writer uses the descriptive qualitative method, because the writer describes the data analyses based on Barack Obama's speeches to find out the result of the research. According to Vanderstoop and Johnstone (2009) a qualitative perspective assumes that knowledge is constructed through communication and interpretation proposed that descriptive method is the research conducted by the fact or phenomena that are empirically exist on the speakers. On the other hand, the descriptive method shows the result of the research based on the writer's attitude or point of view to the use of language.

The writer also uses the qualitative method to analyze the data. The writer makes conclusion through the collected data that are described before. Moreover, the qualitative research method emphasize on analysis with scientific approach.

The data collecting technique depends on the type of research used in qualitative research. The technique of data collection in this study is documentary study. This research applies a documentary study because the data is in the form of document or written text from the transcript of the speeches. Denscombe (2007) argues that documents can be obtained from the internet such as website pages, home pages, or email and they can be treated like online documents.

\section{Result and Discussion}

The data findings show the appearance of types of rhetorical figures, function and coherence of found in Barrack Oabma's Speeches. Meanwhile, the discussion that presents the analysis based on the research objectives of the research. The discussion provides explores the analysis of each rhetorical figures language that used by President of Barrack Obama's andwhat are the functions of rhetorical figures used and is that coherence with the speech. 


\section{Datum 01 \\ On that day of this continent still lay in ruin}

In the text above, Obama states that word continent still ray in ruin that does not mean literally. It does not refer to the continent could divide into many parts of the continent. However, it refers to the condition of many countries like Berlin. The expression above substitute description of condition of Germany country. By saying word metaphor, Obama seems to give impression in his speech for people in Berlin to reveal the conditions of each country such as Berlin which at that time experienced a slumped.

In stating metaphor, Obama does not focus that comparing two objects. Sometimes he spoke only one object that actually applied to another object. By using metaphor Obama is telling of the condition of Berlin before world war. Obama used metaphor to mare attractive speech to ears. Sometime the speaker uses metaphor to explain a condition or even in one word to another word.

\section{Datum 02}

The soviet shadow had swept across Eastern Europe

The utterance the soviet shadow in this expression refers to the condition of Berlin something that seems to be there but actually is not there the expression utterance above substitute describing the condition of Berlin after world war. This word becomes metaphor since the soviet shadow this word is a metaphor as long as the expression conveyed has an indirect purpose or meaning that is not the real meaning, but rather as a figurative expression based on equality and comparison in a word.

\section{Datum 03}

Now is the time to build new bridges

In the previous piece of speech, Obama conveyed America has no better partner than Europe. which refers to Now is the time to build new bridges. The word partner gives meaning to open space in communicating to the European nation especially the German state

\section{Datum 04}

This is the moment when we must defeat terror and dry up the well of extremism that supports it

In that statement above the word defeat terror and dry up the well of extremism is the expression become of metaphor since compared two main topics of problem in the world where are terror and extremism are the problem in their country such as America and Germany. This statement used to describe the problem in that condition after world war in Berlin since sixty years ago in their country. Here, Obama show the defiance of people in the world problem.

\section{Datum 05}

\section{History has led us to a new crossroad, with new promise and new peril}

In the statement above the word of "crossroads" classified as metaphor since the word crossroad refers to that more than a place where the crossroad in their meaning is two roads meet and cross each other, its extended meaning is an essential artery connecting two or more areas and making traffic easier and more convenient. Here Obama compared history to crossroads this word gave stress the conditions significance of this state after sixty years ago, in this expressing Obama wants to tell the audience about are now facing the crossroad such as new promise and new peril his speech in front of people there. 


\section{Datum 06}

Destroying all we have built and all that we love

The phrase statement destroying all we have built and all that we love is the expression of metaphor since the words we have built and all that we love compares to the process condition of progress people in America. This word gave us the audience impression that confidence as an abstract thing treated as a concrete thing which can come across over a land. In this metaphor, Obama wants to tell us that American and German have current condition.

\section{Datum 07}

We stand here tonight is because men and women from both our nations come together

Expressing metaphor in the example above compares the words men and women to all people in Berlin and America. Men and women actually mean people both in same nations. However, Obama mention these words men and women resembles with all both America and German generally. Here, Obama gives the impression that all people have the same objectives for better life. These words are metaphor since men and women comperes.

\section{Datum 08}

These are the aspiration that joins fates of all nations in this city

Speech states by Obama "these" in the word above in that sentence refers to another word before which are "that we can live free from fear and free from want; that we can speak our minds and assemble with whomever we choose and worship as we please" this sentence employ of aspirations. This statement is categorified as metaphor since the word these are the aspiration refers to the aspirations of the people. Thus, this expression described the people condition in aspirations that caused many problems happen in Berlin.

\section{Datum 09}

We are heirs to a struggle for

The word heirs in the sentence means accepting something left behind by the past, namely the task of providing peace in the world in general, in this sentence Obama reveals that our duty is to maintain peace that was left behind by the past so that there is no war like before. In this speech, Obama outlined the many conflicts that occur in the general public so that our duty as fighters today is to provide security to each country this speech implies not to make conflict as before.

\section{Conclusion}

In this research there are two main topic objective, the first is concerned of metaphor that used by Barrack Obama and the second is the indicate of the speech that used and base on the result analysis by Lakof theory and johnson, there are 9 kinds of metaphor that use by Barrack Obama in Address to the people in Berlin where the speech has various meaning with other.

\section{References}

Beekman, John\& Johm Callow. (1974).Translating the Word of God. Grand Rapids. MI:Zondervan. 
Corbett, E. P. (1971). 'Classical Rhetoric for the Modern Student (2nd edition)'. New York: Oxford University Press.

Fajarianti, F. (2008). "Metafora dalam Komik". Skripsi. Fakultas Ilmu Pengetahuan Budaya Universitas Indonesia

GorysKeraf, Diksi dan Gaya Bahasa Jakarta : PT GramediaPustaka Utama, 2002.

Gove. (1981). Webster's Third New International Dictionary. The USA: G. \& C. Merriam, 01.

Lakoff, G \& Mark, J. (2003). Metaphors we live by. London: The University of Chicago Press.

Vanderstoep, Scott W and Deirde D. Johnston. (2009). Research Methods for Everyday Life. San Francisco: Jossey- Bass. Verdonk, P. 2002. Stylistics. Oxford University Press.

Willis, H. (1969). Structure, Style, and Usage. New York: Holt, Rinehart and Winston Inc.

Zheng Lingling, The Analysis on Obama's Two Inaugural Speeches from the Perspective of Neo-Aristotle's Rhetoric, [D], An Hui University, 2014.

\section{Copyrights}

Copyright for this article is retained by the author(s), with first publication rights granted to the journal. This is an open-access article distributed under the terms and conditions of the Creative Commons Attribution license (http://creativecommons.org/licenses/by/4.0/). 